\title{
Shakespeare's resurrected sisters: Emily Dickinson and Sylvia Plath
}

\section{Muneerah B Almahasheer}

(Department of English)

College of Arts in Dammam,

University of Dammam, 



\title{
Shakespeare's resurrected sisters: Emily Dickinson and Sylvia Plath
}

\begin{abstract}
"Shakespeare's Resurrected Sisters: Emily Dickinson and Sylvia Plath" is an overview of the oft-neglected collective female poetic tradition from the 17 th to the 20th centuries that is meant to identify the common themes that run through these works as describes in Shakespeare's Sisters: Feminist Essays on Women Poets (Gilbert and Gubar, 1979). It signifies the resurrection of the poetic creativity in female poets as they are straining against the roles imposed on them by the Western patriarchal tradition. It then focuses on how their attempt to rebel against the Western patriarchal tradition is expressed in a speculation on Woolf's image of the so-called Shakespeare's Sisters, on the poetry of Emily Dickinson and Sylvia Plath that crystalizes the commonalities that tie these writers within the trajectory of female poets. Keywords
\end{abstract}

poetic tradition, poems, feminine, women, domesticity, patriarchal.

Shakespeare's Sisters: Feminist Essays on Women Poets (hereafter Shakespeare's Sisters, Gilbert and Gubar, 1979) unveils the female poetic tradition that has previously been disregarded, denigrated and misread. A poetic tradition of recurring thought, themes, images, conceits and diction. In A Room of One's Own, Virginia Woolf speculates, regarding the anguish of Shakespeare's sister, that she would have gone mad or killed herself if she had not written a word. 
She then confidently argues, "Give her a room of her own and five hundred a year, let her speak her mind and leave out half that she now puts in, and she will write a better book one of these days" (2015:93). This paper aims to be an alterable speculation on Woolf's image of the so-called Shakespeare's Sisters on the poetry of Emily Dickinson and Sylvia Plath; their works have outlived their tragic and untimely ends, allowing them to survive in verse. This paper is divided into two parts; the first part provides a detailed reading of the Shakespeare's sister poets, tracing the outline of the distinctively female poetic tradition described in Shakespeare's Sisters: Feminist Essays on Women Poets (Gilbert and Gubar, 1979). The second part of this paper is a comparative feminist reading of the poetry of the $19^{\text {th }}$ and $20^{\text {th }}$ century poets, Emily Dickinson and Sylvia Plath. In this section, I examine the commonalities of thought in their poetic tradition, presenting both poets as Shakespeare's sisters not by birth, but by poetic rights.

In the Norton Anthology of Literature by Women, Gilbert and Gubar have remarked that "female poets both participated in and diverged from the literary conventions and genres established for them by their male contemporaries" (1996: 79), while in The Madwoman in the Attic they consider verse genres to be "more thoroughly male than fictional ones" (2000: 68). Gilbert and Gubar also coined the symbol of the pen as Penis in English literature, while Harold Bloom related father imagery to poetic creativity in terms of Freudian imagery as influence, and feminized the Muse as the mother-harlot (Brogan, 1993: 405). A related concept is CG Jung's idea of the animus as the shadow of creativity: "The encounter with the shadow is the 
apprentice-piece in the individual's development ... that with the anima is the masterpiece" (Stevens,1990: 206). The animus may signify the diverse male personalities "of a collective rather than a personal element" (Von Franz, 1978: 206). Thus, this paper assumes that the female consciousness of the Western patriarchal bias is a collective consciousness that regenerates itself. Female poets have tried to mask their voice as male shadows to avoid the metaphysics of verse and the masculinity of their society.

\section{The collective female poetic tradition}

In Shakespeare's Sisters, Gilbert and Gubar have attempted "to pass on a [female poetic] tradition," in order to "to know the writing of the past" and the patriarchal structures and obstacles "that discouraged women from attempting the pen" (1979: xv). In this section, I will give a brief overview of some of the main players in that tradition.

In the $17^{\text {th }}$ century, it was considered improper for a woman to publish her writings. A notable exception was Jean Lead (1624-1704) who was viewed as a visionary rather than as an artist. Lead "wrote outside of the literary mainstreams ... [she] had illuminations and formed congregations outside of institutionalized religion" (Gilbert and Gubar, 1979: 11). Anne Bradstreet (1624-1704) was a clever observer of the Puritan restrictions on what can be labeled the "feminine role," feminine domestic role, that form the core of her poetry. She published with the help of her brother-in-law, Reverend John Woodbridge, which was considered a "practical way to circumvent the accusation of [the dangerous female] excessive 
ambition" (Gilbert and Gubar, 1979: 27). Bradstreet's poetry draws a unified universe rather than a patriarchal-dominated one, while balance is achieved through a "mutual interaction" between the sexes (Gilbert and Gubar, 1979: 28). Anne Finch (1624-1704) was an Augustan poet who lived in a male-oriented period. She adopted the masculine tradition, working within the Augustan norms (i.e. mock, epic verse, etc.) to announce her feminine voice, and her poetry expresses her views of marriage and men. The institution of marriage, she believes, is "hypocritical and restrictive" (Gilbert and Gubar, 1979: 36). Marriage is a male creation that is intended to restrict women far more than men. Furthermore, she blames society and culture for female ignorance and foolishness: "Education's, more than Nature's fools" (Gilbert and Gubar, 1979: 39). In her love poems, women are the subjects and they are seen free sexual walls.

Like their predecessors, 19th-century female poets imitated the dominant male poets and celebrated standards whereby female authors should remain women. They also suffered the consequences of The Scarlet Letter, the shame for attempting the pen that is symbolically male oriented penis. Indirectly, Emily Brontë's poetry (1624-1704) shows vivid echoes of Wordsworth, Byron and Blake. Throughout Gondal poetry, that navigates away from her father's parsonage, Brontë challenges patriarchal dominance in her quest for freedom, struggling "Betwix the pain to live and agony to die" (Gilbert and Gubar, 1979: 270-275). She longs to break the chain of possessive love and calls for liberty (Gilbert and Gubar, 1979: 54). 
Another female poet, Elizabeth Barrett Browning (1624-1704) declares the love of "the grandfathers" as role models (Gilbert and Gubar, 1979: 65), and refuses to admit that there were restraints on women's poetry since its subject matter can be "anything and everything which honestly illuminates her life" (Gilbert and Gubar, 1979: 67). She also battled for a rigorous evaluation of women's poetry. By the age of 12, Barrett Browning had been influenced by Mary Wollstonecraft's A Vindication of the Rights of Women, which may explain her self-consciousness as a female poet who liked to step beyond the limits. She also faced publishing problems when the novelist William Makepeace Thackeray refused to publish "Lord Walter's Wife" in Cornhill Magazine, claiming that "the corruption of our society requires not to shut doors and windows, but light and air" (Browning, 1897: 44)

Christina Rossetti (1624-1704), like other Victorian poets, was concerned with the duality of standards. Her poems reflect an awareness of "references to faces, masks, veils, shrouds, and less frequently, bodies fixed in an attitude" (Gilbert and Gubar, 1979: 83). Vulnerability and self-pity fuel Rossetti's poems.

For Emily Dickinson (1830-1886), home provides a sense of protection and freedom. Only ten of her poems, and some without her consent, were published during her lifetime, while nearly 2000 poems remained unpublished. Although she assigned a masculine gender to herself when personifying those parts of herself that she considered unfeminine, a way to assert littleness. Dickinson shares Rossetti's 
need for a mask to write behind (Gilbert and Gubar, 1979: 108). Furthermore, she was eager to gain her selfhood: "With Will to choose or to reject"( Dickinson,1975 247). Emily Dickinson is "endowed to speak for those who do not have the gift of language" (Gilbert and Gubar, 1979: 119).

The Afro-American female poets have also been degraded, discounted and discredited. Early Afro-American poetry is characterized by the dazzling sexual identity of the speaker, who cannot be recognized as either male or female. One of these female writers is Phillis Wheatley (1753-1784), who wrote about dead ministers and through abstractions to illuminate the gender bias that controls the society. Frances Harper's poetry (1825-1911) mainly concerns the "religious, feminist, temperance movement" (Gilbert and Gubar, 1979: 168). Unlike other black American poets, Georgia Johnson's poetry (1880-1966) has a definitively feminine voice. She represents a radical change in black American poetry, which affected other poets. Anne Spencer, for example, has a sense of her "womanself and [of] a female identity" (quoted in Gilbert and Gubar, 1979: 172). A more radical black American poet is Helen Johnson (19061995), who wrote racial protest poems. While the aforementioned poets could not even participate in the Harlem Renaissance, things changed and Gwendolyn Brooks (1917- 2000) was the first black person to win the Pulitzer Prize for her 1945 volume A Street in Bronzeville. Contemporary black American poetry, like that of Sonia Sanchez (1934), presents various subjects including the crisis in racial identity, civil rights and black womanhood. Audre Lorde was unable 
to publish her poems before the second wave of feminism since much of her poetic production explores issues of female identity and sexuality, including lesbian themes. Contemporary black American poetry, like that of Sonia Sanchez is more liberated and touches upon drastic subjects, including the crisis in racial identity, civil rights and black womanhood.

Modernist female poetry is revolutionary for its enhancement of the space of expression. The modernist Edna Millay (1892-1950) declares her awareness of the universality of women's vulnerability and anguish. She believes that women are tragic and heroic. She expands the suffering of women "whose dreams are denied, whose bodies are assaulted" (Gilbert and Gubar, 1979: 198). Hilda Doolittle has remained conscious of the mythic, scientific and linguistic symbols used by men. She affects her readers with her search for female divinity and prophecy. She tries to mythologize "her self," her and everywhere as well as her gender and recreates a new universe.

Meanwhile, May Swenson (1913-1989) dwells on feminist themes, and her poetry lacks any trace of the archetypal masculine will. Sylvia Plath's poetry (1932-1963) is typically feminist. It enacts the psychodrama of the self to destroy the patriarchal presence: "the self splitting, doubling, mythologizing the self until it hardly seems any longer to have an existence within itself" (Gilbert and Gubar, 1979: 250). Plath's poetry is a mature version of Shakespeare's sisters' $19^{\text {th }}$ and 20th-century poetry, which conveys a feminine sense of entrapment. In the midst of her struggle for salvation, Anne Sexton 
has been looking "for a way out of madness ... a way that is not suicide" (Gilbert and Gubar, 1979: 262). However, her poetry has increased her sense of "self-fragmentation" rather than wholeness (Gilbert and Gubar, 1979: 268). Likewise, Denise Levertov (19231997), Muriel Rukeyser (1913-1980) and Adrienne Rich (1929-2012) found that it is the inherited consciousness that is responsible for the narrowing of women's options. They attack traditional patterns of perception and attitude, encouraging other female poets to examine the political forces that form the individual consciousness, since the political is the personal.

There is no doubt that the trajectory of female poetic tradition from the $17^{\text {th }}$ to the $20^{\text {th }}$ centuries is a story of a common theme that is a need to have a voice of their own. It is not necessarily that every poet demonstrated a poetic gift but most of them shared the urgeness that turned into a recurring theme of women attempting the pen, a historical and psycological resurrection of a poetic gift espeacially with Emily Dickinson and Sylvia Plath.

Shakespeare's resurrected sisters: Emily Dickinson (1830-1886) and Sylvia Plath (1932-1963)

Seventy-four years after Emily Dickinson's death (1830-1886), her poetry was collected in The Complete Poems of Emily Dickinson, an icon of revolt against the patriarchal institutions and metaphysical subversive expectations and chains. Dickinson turned her back on the patriarchal times in which she lived and the literary conventions handed to her by tradition. She thereby became America's 
distinguished late nineteenth century woman poet. Likewise, the autobiographical tone and concrete determination of Sylvia Plath's (1932-1963) poetry, fiction and prose made her one of the most promising feminists of her generation.

Although Emily Dickinson and Sylvia Plath lived in different eras, they share a parallel feminine reluctance and reservation about publication. Dickinson experienced the agony of having her lines conventionalized by editors, without her knowledge or permission. She was reluctant to expose her nontraditional work, equating the art of publishing under male censorship, "Mind of Man," to the act of selling someone's soul, "Publication - is the Auction / Of the Mind of Man-." Due to the impolite interference of misogynistic publishers, the "Mind of Man" can be the poet's mind as well as the combined mind of the publisher who imposes his thought on the discourse, in an auction of papers rather than meanings and thoughts. She warns all writers not to reduce their poetry or art "To Disgrace of Price-." She further prefers to present herself and poetry as that of "I'm Nobody!" \#288 (Dickinson,1975:133) rather than a poet like annoying frog "Somebody! / How public_like a Frog_" (Hoefel: 2000). Similarly, Plath authored a single novel, The Bell Jar, which was frustratingly published in England under the pseudonym Victoria Lucas, because she didn't want to hurt the feelings of close friends/acquaintances who featured in the novel, and as a consequence of the masculine dominance of pen and publication. 
Both poets were disheartened by masculine love, loss or betrayal, which influenced their feminist identity. A source of debate in Dickinson's personal letters is the identity of the "Master" in her passionate "letters." Some critics propose that this mysterious lover was the Reverend Charles Wadsworth, who was never been aware of her deep affection and to whom she addressed many of her finest poems. Betrayal is a depressing love story that has caused Sylvia Plath's heartbreak in 1962. According to Ted Hughes, it was around Christmas of 1962 when Plath selected the poems for Ariel, which was a poetic document of that heartbreak beginning with "Morning Song" and concluding with "Wintering," opening with "Love" and closing with "spring," notably. Marjorie Perloff contends that, in the same summer of 1962, Ted Hughes delayed and omitted 12 of his wife's poems from the planned verse publication as they reflect her anger and despair over his infidelity causing the poet's suicide. It was "the actual dissolution of the Plath-Hughes marriage, that Sylvia finally stopped 'producing' poems as she had produced babies, in order to please and impress her mother, and, by extension, 'all our friends and relatives,' editors, and contest judges" (Perloff, 1979: 156).

As a female poet born into a patriarchal Calvinist and Puritan society of extravagant Shakespearian "Somebody" "Public Frog" male writing and publishing, Dickinson had few choices that dominated her conservative feminine lines. Unlike Plath's "I" as the first-person reference and search for identity, the "I" in Emily Dickinson's is a collective feminine "I." Her poetry articulates Shakespeare's sisters' challenge to have a voice and a pen of their own. A pen or a purpose 
that breaks them free of the enforced limits on prose (Dickinson,1975: 302), and acknowledges their sexual identity (Dickinson, 1975: 429).

In \#613 the speaker (supposedly a female poet or a young girl like Plath's juvenile female speakers) identifies the enforced constraints of a masculine society that prefers a prose writer over a female poet, comparing the act of censorship to a "closet" and the intimidated feminine poet to nothing more than a rag. A society that demoralizes its gifted minds to "shut up" and "liked" them to "still." Ironically, the imposed "closet" or cage of "a bird" has never prevented the bird from abolishing "his Captivity" to sing and "laugh" celebrating victory:

They shut me up in Prose-

As when a little Girl

They put me in a Closet-

Because they liked me "still"-

Still! Could themself have peeped-

And seen my Brain—-go round-

They might as wise have lodged a Bird

For Treason-in the Pound-

Himself has but to will 
And easy as a Star

Abolish his Captivity-

And laugh-No more have I- (Dickinson, 1975: 302)

Apparently, the speaker compares her powerlessness to that of a "little Girl" whose "Brain" is entrapped in the "prose" "closet," which symbolizes the limitation of prose in comparison to poetry of "prose" to poetry, as she believes. The negative images of the first line suggest that Dickinson did not regard prose highly, but rather revolted against conventionalizing female writers and against covering up her poetic mastermind. In a letter, Dickinson wrote, "We please ourselves with the fancy that we're the only poets, everyone else is prose" (Erkkila: 1992, 29), and in poetry she declares that "I dwell in Possibility_ / A fairer house than Prose_-" (Dickinson, \#657 1975: 327). Writing poetry to Dickinson is a sort of madness associated with hysterical joy and laugh, the speaker transcends into a state of consciousness to trace poetic growth while her "Brain_-begun to laugh_-"

And Something's odd—within-

That person that I was-

And this One - do not feel the same-

Could it be Madness_- this? (Dickinson,1975: 195)

She likens the joy of poetic creativity to the symptoms of increased madness. 
Dickinson's life and mind have turned into "- - L Loaded Gun" (Dickinson, \#754 1975: 369-370). The poet's threatening views and ideas are projected from the point of view of "a Loaded Gun." This poem, which begins in a typical scene of an American hunting trip evolves into a poem of a divided self, the lines into the trees of the woods, a self that is urging for adventure in dangerous environments, which the pen or the line transform into a securing gun. Independence, power, fear and pleasure are integrating and dissolving into a final success when the gun is pulled from her reverie of having the power to be heard. The victory of power is a final conquering that echoes.

At this point, one of the most significant questions posed by the poem becomes clear: for whom in the $19^{\text {th }}$ century would pleasure and power be problematic should they be expressed? If one asserts that the speaker of the poem is female, another dimension is added. The poem then depicts not merely the plight of a speaker who is dependent on the actions of another for the release of its power, but the plight of a female speaker who must-because will and power have traditionally been characterized as masculine qualities - identify extensive portions of her female self as masculine.( Estes,2000)

For this speaker to express her power is for her to "hunt the Doe, a voice of revenge similar to Plath's misandrist meanings. In this way, Dickinson's poem questions society's notions both of power and of the appropriate means for its expression, specifically the way in which ideas concerning power are constructed with respect to males and females. 
The self merging into power dominates the poem and loads its lines, reflecting Dickinson's strong poetic voice, which is "a Loaded Gun." A voice that never lacks potential supremacy yet is intact and silenced ("a Loaded Gun- / In Corners") until it has been recognized or "identified" by its "Owner," who might be the poet herself, who then decides to carry it into the quest, \#754, "We roam in Sovereign Woods" (Dickinson,1975: 369-370). Not only this, but the roles reverse into "And now We hunt the Doe," with the use of "now" signifying power, pleasure and chance. The speaker's determination of power is growing, changing "the We" into an emerging and stronger eccentricity as an "I" in "And every time I speak for Him - / The Mountains straight reply" (Dickinson,1975 369-370). The speaker thereby seizes the right to speak vociferously. Compared to the past, when the speaker's life was lost and marginalized "In corners," unnoticed, like a wallflower, the strong use of "now" demonstrates the shift of place as nature immediately takes notice of her ("The Mountains straight reply”) (Dickinson,1975 369-370).

Unlike Dickinson's universal "I," Plath's “I" is more personal and confessional, for she draws on the personal details of her life as the subject matter. Plath's personas in Ariel experience ritualistic death and rebirth, with numerous subthemes including the struggle to find true identity (the search for the real self and the killing of the false one), the destruction of a tainted experience and regeneration of a pure one and the innocence of childhood and the evils of the adult world. Several of the poems in Ariel invoke this theme of the difficulties of living a free and unhampered life in the eye of societal 
expectations. Curiously, images of the liberated-self are progressive and optimistic while images of a self bound to another, or married, are doubting and pessimistic. Plath's poems revel in her own selfsufficiency and self-expression.

Dickinson's eagerness for love contrasts with Plath's quest to destroy the last one on earth. Plath's personas are a developed version of Dickinson's Gun, which not only speaks or Kills without dying, but is a proactive killing machine that takes revenge on all men around. In "Wintering," Lady Lazarus eats men and "winter is exclusively for women" (Plath, 1981: 246). The daughter in "Daddy" is a serial killer who figuratively kills all men, revolting against the fabricated self she has become: a timid, terrified shadow living in the male-dominated world of evil. Released, Plath's females can be reborn and regenerated like the phoenix that enjoys the benefits of new beginnings, or the potentials of a newborn baby, an image Plath often uses (Plath, 1981: 223).

Sylvia Plath's relationship with her father, who died when she was only eight-years old, is the subject of much of her poetry, which she reincarnates within the figure of the oppressor. Therefore, the father image remains an alienated image, an alterable image, while the daughter image suffers a split off from the subject, father, and becomes a subject of repression wishing for the return of the suppressed.

Plath's pre-school image of Humpty-Dumpty in "The Colossus" is a challenging obsession. The corpse/statue/patriarchal image cannot be "pieced, glued, and properly jointed" (Plath, 1981: 
129) together, physically and psychologically. The speaker's head poses a problem to Plath's girl, as she tries to identify the impenetrable head, from the lips to the brow, the eyes and the hair moving from childhood dreams into adulthood land of awareness, from the art of cut and paste to the art of resurrecting Frankenstein. It is not until the fourth stanza that the ambiguous identity of the "you" is finally revealed, when she declares explicitly that the you she is trying to "piece" and create, the one she is trying to absorb and listen to is, in fact, the Girl's father. The girl's demiurgic role is unique, or her wish to create an archetypal father image, crawling all over his "skull plates" (Plath, 1981: 129), trying to "clean" (or remove things she does not want to remember or to have in this new prototypical father). The poem is emotionally confusing, as the speaker is mending herself through mending the scattered image of the father.

The image of the huge burial ground, as well as the killing silence is perplexing the girl in the final stanzas. During the nighttime, the child protects herself from his shadow by squatting "in the cornucopia / Of [his] left ear" (Plath, 1981: 129), waiting, but unfortunately hears nothing from him. It is a speechless scene of Godot waiting for an answer. The sunrise that comes "from under the pillar of [his] tongue" (Plath, 1981: 129), rises mutely as if to substantiate that her Frankenstein will not be a living creature and that the deceased father will never return, the ground she is in, is a burial of a lost paradise that will never be regained. 
The fact that the father lies scattered across the poem, littering the horizon, perhaps suggests the ambivalence the poet feels for her father. On one hand, she wants to be reunited with him, but, on the other, the image she creates of a dismembered ruin perhaps suggests her anger at her father, her husband, or in general, a feminist recurring theme in Plath's poetry.

Plath explicitly publicizes, "I have had to kill you" (1981: 222) in a wished-for murder of the "Daddy" figure. The poem one word title becomes the conceit of all images and figures. The departed, titanic patriarch, is characterized as "Marble-heavy, a bag full of God," and "Ghastly statue," decentralizing corpses and ghosts (Plath, 1981: 222). The gigantic description of the father with "one gray toe / Big as a Frisco seal" and "A head in the freakish Atlantic" ironically echoes the unusual patriarchal imagery of "a bag full of God" (Plath, 1981: 222). The female speaker becomes completely alienated and arouses pity and oppression when she admits that she could not talk to her God/father: "I never could talk to you. / The tongue stuck in my jaw" (Plath, 1981: 223).

In the seventh stanza, the speaker personifies herself as a Jew to dramatize her revolt against the misogynistic Nazi father in a Holocaust scene. Leondopoulos explains how Daddy's unusual daughter "identifies herself with gypsies, another group much hated by the Nazis"(2002). She continues teasing the father, mocking his Fascist discourse as "gobbledygoo" (Plath, 1981: 223), as well as his Nazi appearance: "And your neat mustache / And your Aryan eye, 
bright blue. / Panzer-man, panzer-man, O You_-" (Plath, 1981: 222) (Leondopoulos,2002). The angry child rages against her Daddy, comparing him to "Not God but a swastika / So black no sky could squeak through" (Plath, 1981: 222), a male devil who is capable of overpowering the heavens, and devouring humans.

The ritualistic murder of the father takes place after he becomes a vampire in the fifteenth stanza. The piteousness of the poem is increased with the word "black," which is used to describe the Daddy's "fat heart" as "There's a stake in your fat black heart / And the villagers never liked you" (Plath, 1981: 224). More anger and oblique sorrow comes throughout the speaker's decisive, triumphant murder as, "Daddy, daddy, you bastard, I'm through" (Plath, 1981: 224), a declaration of freedom from the Oedipal prison-house. This line signifies an assertion to the feminist awareness as it deconstructs the previous assumption that "Every woman adores a Fascist" (Plath, 1981: 222). The poem is a celebration of sadness and conquest. She is no longer the passive "old woman who lived in a shoe ... [who] didn't know what to do."

You do not do, you do not do Any more, black shoe In which I have lived like a foot For thirty years, poor and white, Barely daring to breathe or Achoo. (Plath, 1981: 222) 
Daddy's girl, however, is a woman who releases herself of her 30-year demeaning entrapment in her old man's shoe as a foot, with all the atrocious significations of terrorization, disgust, apathy and misogyny. In fact, selected poems interject the writer's bias towards males in general. The Daddy figure stands for the masculine world as a Nazi, a Fascist, a ghost, a vampire and sometimes reincarnates as the devil himself.

To understand the dualistic feminist side of Dickinson's poetry, then, is to recognize the marginalized situation of women in $19^{\text {th }}$ century America. Legally and physically, women were powerless and an oppressed half in a patriarchal capitalistic system. In an attempt to dissociate self, mind and world, Dickinson strives to voice the voiceless, to see for those who are less active and to create a poetry of extreme states that allows others to go further into their responsiveness and perception. She had the art to convey in poetry her experience of reality. For Dickinson, there were both surfaces and evasive underlying meanings.

Stimulatingly, in \#303, the soul—gendered as feminine_- "selects her own Society_-" and is astoundingly related to action verbs "selects", "shuts", "present" "notes" and "choose".

The Soul selects her own Society-

Then-shuts the Door-

To her divine Majority- 
Present no more-

Unmoved-she notes the Chariots-

pausing-

At her low Gate-

Unmoved—an Emperor be kneeling

Upon her Mat-

I've known her-from an ample nation-

Choose One-

Then-close the Valves of her attention

Like Stone- (Dickinson, 1975: 143)

Significantly, "The Soul Selects Her Own Society" can be viewed as a portrayal of the artist's feminist attitude: the Soul, perhaps Dickinson, liberally decides to shut herself off from the world to attain self-realization. Apparently, the soul is feminine, "her," that is, an active subject who is able to "select" and "shut the Door," indicating barriers and restrictions. The imagery of this irregular soul is of one who selects "her own Society," disregards the Chariots pausing at her gate and discourages emperors who are coming to visit, not letting them in. This suggests that she breaks the social norms and rules of decorum. Even the Emperor, who stoops to conquer, falling on his knees before her door, is not allowed to enter or be heard. The Soul, clearly, has closed her attention to everything except "One" thing, 
which might be her own eccentric self, comparing this decision to a "stone," which means it is final.

In other poems, Dickinson provides detail of the "Door" as the "retaken moments," and herself as a world prisoner living physically and psychologically in outer- imposed walls that separate her off from what she loves most to know. She refuses the Darwinian theory of natural selection as well as the ascendancy of the natural order by predominantly male scientists in (\#70):

"Arcturus" is his other name-

I'd rather call him "Star."

It's very mean of Science

To go and interfere! (Dickinson, 1975: 36)

She questions the scientists' theoretical ivory towers for thinking they can objectively know nature while detaching themselves, acting like monsters "with a glass / Computes the stamens in a breath - / And has her in a "class"' (Dickinson, 1975: 36). In a way, she is mocking the male tendency to objectify everything, even another of nature's inferior productions, i.e. woman. The word "class" symbolizes the scientist's objective classification. It also connotes the word "house" as a confinement where he has "her," the woman, as a prisoner.

Dickinson concludes the poem with a controversial line that confronts the role of the majority for the sake of originality and 
individuality by hypothesizing the sacrifice of writing poetry as the "divinest sense" of "much" "Madness."

Much Madness is divinest Sense-

To a discerning Eye-

Much Sense - the starkest Madness-

'Tis the Majority

In this, as All, prevail-

Assent - and you are sane-

Demur-you're straightway dangerous-

And handled with a Chain- (Dickinson, 1975: 209)

The speaker is aware of the consequences of labeling her as mad and the expected "chains" to be tamed and rehabilitated her. Nevertheless, she is also convinced of the appropriateness of her "discerning Eye," preferring her madness over the society sense. She pays the price for her individuality, rebelliousness and originality, even if it is "straightway dangerous - / And handled with a Chain."

Plath's disseminated society is an imitative modern version of Dickinson's choice to "select her own Society_." Plath represents a growing feeling of female resistance to the expectations of the middleclass family. In Ariel, as in much of Plath's work, a woman's revolutionary voice and words of action dominate as well as a woman's perspective. If Dickinson has chosen to confine herself to her home and the natural images of birds, flowers, flies, frogs, sunrise 
and sunset and doors, Sylvia Plath is also lured from the traditional female anxieties of householding and mothering. While Dickinson chooses to shut the "Door" on male emperors and societal "Madness," Plath was more radical by the ideal roles she felt bound to play as a woman. She revolted against all the social roles and "rules" that turn her into nothing more than a "A Birthday Present": "adhering to rules, to rules, to rules," and relentlessly asking for death as a birthday present. The act of death is nothing more than a means to be resurrected repeatedly overcoming the misogynistic males.

In "The Couriers," radical themes of love and marriage dominate and vary into two different phases of feminine awareness. The first is the denial phase of what can be a romantic image of marriage that is associated with deception and pain: "A ring of gold with the sun in it? / Lies. Lies and a grief' (Plath, 1981: 48). The second is the identity phase, the existence of individuality in love as "Love, love, my season," and determines the poet's unique way of loving, apart from the norms of society (Plath, 1981: 49). She confronts the prefixed societal role of a woman that is not supposed to exceed the limits of wedding and mothering in favor of a role with the choice to love and be loved, a role in a healthy relationship that is more than a birthday gift. Plath's later poems continue the stereotypical theme of "The Couriers," except that, in them, the woman did not succeed to get an identity of her own, she is rather trapped and suffering. In "The Applicant" the wife is a servant in a prison like house acting as "A living doll, everywhere you look. / It can sew, it can cook, / It can talk, talk, talk. / It works, there is nothing 
wrong with it" (1981:221) Love feelings and feminine identity of "The Couriers" are completely absent in the woman stereotypical figure of the "living doll" of "The Applicant."

In modern American society, Plath finds out that "Every woman adores a Fascist, / The boot in the face, the brute / Brute heart of a brute like you" (1981: 222). This degrading masochistic proclamation explains, from a feminist poet's viewpoint, the male presuppositions of what "Every woman" adores. The feminist penetration endures in the subsequent image of the father as teacherdevil, a traditional gender role of male tutors.

The father image is also prototyping "Lady Lazarus," reflecting the desire to vengeance that is endured by the female protagonist in a mythical setting. The poem title, "Lady Lazarus," ironically disseminates the traditional idea of lady-like behavior. The lady is an outrageous monster who has been brutally and is brutally slaughtered and who is taking revenge on the society of men. The "Lady" is also an egocentric figure, using "I" twenty-two times, and "my" nine, thus resurrecting herself repeatedly (Heaton, 2002). Like a cat, she allows herself nine lives, something that, even if difficult is still "manage(able)" (Plath, 1981: 244), assuring both her honor and victory.She resurrects with the "same brute" every time, opening with her tenth year, and it is no surprise to discover that she, as a conventional Plath protagonist, intends the destruction of "men," starting with the instinctual brute who is always the father. This 
explains why Plath renders the customary "Ladies and Gentlemen" as “Gentleman, ladies" (1981: 245).

The father is the enemy who symbolizes society's viciousness against all women. He is the sadist who victimizes Lady Lazarus victimization for being "Herr Enemy" (Plath, 1981: 245) and "Herr Doktor" (1981: 245). The father is the German stereotype of "Daddy," a curse that is the source of life and cause of death; thus, this ominous persecutor, which is reminiscent of the Nazi concentration camp at Auschwitz, becomes patriarch to her "art" of resurrection. The materialistic relationship that connects them makes the lady a valuable "pure gold" (1981: 245), and there will be a "very large" price for "eyeing scars," and for examining how the lady's heart "really goes" for a "bit of blood" or "word" (1981: 245). Lady Lazarus warns all men (as well as the patriarchal society) that she will keep rising as a phoenix, and will enjoy taking revenge and consume all men as fire does oxygen.

The poetry of both poets is critical to feminist writing in the United States. They are poets of great sensitivity to subversiveness and both had lively intellects. They were simultaneously aware of the joys and psychic terrors of challenging their tradition, altering the metaphysical standards of language, images and themes to dismantle and disseminate their usual meaning. Their poetry reflects women's struggle to cope with their socially doctrinaire roles as giving females (daughters, lovers, wives and mothers) and with their contradictory human needs for independence and individuality. The ambivalent 
tension between the lure of life and the fascination of death and the need to fulfill the expectations of others, which challenges the need to fulfill the demands of self, pervade both poets' feminist literary work. 


\section{References}

Browning E (1897) Letters. In: Frederic GK (eds) New York: Macmillan.

Bennett P (1990) Emily Dickinson: Woman Poet. Iowa City: University of Iowa Press.

Bogan L (1960) A Mystical Poet. In: Emily Dickinson: Three Views. MacLeish A, Bogan L and Wilbur R (eds). Amherst, MA: Amherst College Press, pp.27-34.

Brogan T (1993) The New Princeton Encyclopedia of Poetry and Poetics. Princeton, NJ: Princeton University Press.

Butscher E (1976) Sylvia Plath: Method and Madness. New York: Seabury Press.

Collins T (1998) A Review. The Explicator 56(3): 156-159.

Dickinson E (1975) The Complete Poems. In: Johnson TH (eds) London: Faber \& Faber.

Dunlap, A. Jordan. Masterplots. $2^{\text {nd }}$ ed. Pasadena, Caifornia: Salem Press, Inc.

Estes, A. Masterplots. $2^{\text {nd }}$ ed. Pasadena, Caifornia: Salem Press, Inc.

Erkkila ,B. (1992). The Wicked Sisters : Women Poets, Literary History, and Discord: Women Poets, Literary History, and Discord . Oxford: Oxford University Press.

Ferlazzo P (1976) Emily Dickinson. Boston: Twayne.

Gilbert S and Gubar S (1979). Shakespeare's Sisters: Feminist Essays on Women Poets. Bloomington: Indiana University Press. 
Gilbert S and Gubar S (1996). The Norton Anthology of Literature by Women: The Traditions in English. $2^{\text {nd }}$ ed. New York City: Norton.

Gilbert S and Gubar S (2000). The Madwoman in the Attic: The Woman Writer and the Nineteenth-Century Literary Imagination. New Haven: Yale University Press.

Heaton D (2002). Masterplots. $2^{\text {nd }}$ ed. Pasadena, Caifornia: Salem Press, Inc.

Hatfield CW (1995) The Complete Poems of Emily Jane Bronte. New York City: Columbia U Press.

Juhasz S (1983) Feminist Critics Read Emily Dickinson. Bloomington: Indiana University Press.

Kroll J (1976) Chapters in Mythology: The Poetry of Sylvia Plath. 1st ed. New York City: Harper and Row.

Leondopoulos, Jordan. Masterplots. $2^{\text {nd }}$ ed. Pasadena, Caifornia: Salem Press, Inc.

Dunlap, A. Jordan. Masterplots. $2^{\text {nd }}$ ed. Pasadena, Caifornia: Salem Press, Inc.

McNeil H (1987) Sylvia Plath. In: Vendler H (eds) Voices and Visions. New York City: Random House,469-96.

Miller R (1978) Emily Dickinson. In: Myerson J (eds) The American Renaissance in New England. Detroit: Gale Research, pp.34-35.

Orr S (1995) Dickinson’s “I taste a liquor never brewed--." The Explicator 53(4): 212-214.

Perloff M (1979) Sylvia Plath's “Sivvy” Poems: A Portrait of the Poet as Daughter. In: Lane G (eds) Sylvia Plath: New Views on the Poetry. Baltimore: Johns Hopkins University Press, pp.155-178. 
Perloff M (1981) Sylvia Plath's “Collected Poems": A Review-Essay. In: Resources for American Literary Study (11)2: 304-13

Phillips R (1973) The Confessional Poets. Carbondale: Southern Illinois University Press.

Plath S (1977) Context. In: Hughes T (eds) Johnny Panic and the Bible of Dreams. London: Faber \& Faber, pp.92-93.

Plath S (1981) Collected Poems. In: Hughes T (eds) London: Faber \& Faber.

Plath S (1962) Johnny Panic and the Bible of Dreams: Short Stories, Prose and Diary Excerpts: New York: Harpor.

Porter D (1966) The Art of Emily Dickinson's Early Poetry. Cambridge, MA: Harvard University Press.

Rosenbaum SP (1964) Concordance to the Poems of Emily Dickinson. Ithaca, NY: Cornell University Press.

Rosenberg E (1987) Sylvia Plath. In: Layman R and Tarbox L (eds) Concise Dictionary of American Literary Biography: The New Consciousness, 1941-1968. Gale Research Company, pp.408-422.

Sewall R (1980) The Life of Emily Dickinson. New York: Farrar, Straus \& Giroux. Stevens, S (1990). On Jung. London ; New York: Routledge.

Tate, A (1948) Emily Dickinson. In: On the Limits of Poetry: Selected Essays, 1928-1948. New York: Swallow Press, pp.197-213.

Von Franz, ML (1978) The Process of Individuation. In: Jung C (eds) Man and his Symbols. London: 
Wagner L (1984) Critical Essays on Sylvia Plath. Boston: G. K. Hall \& Co.

Wolff CG (1986) Emily Dickinson. New York City: Alfred A. Knopf.

Woolf, V (2015) A Room of One's Own: And Three Guineas. Oxford: Oxford University Press. 